e-ISSN: 2721-3013, p-ISSN: 2721-3005

DOI: https://doi.org/10.38035/jafm.v1i2

Received: 3 April 2020, Revised: 27 April 2020, Publish: 20 May 2020

https://creativecommons.org/licenses/by/4.0/

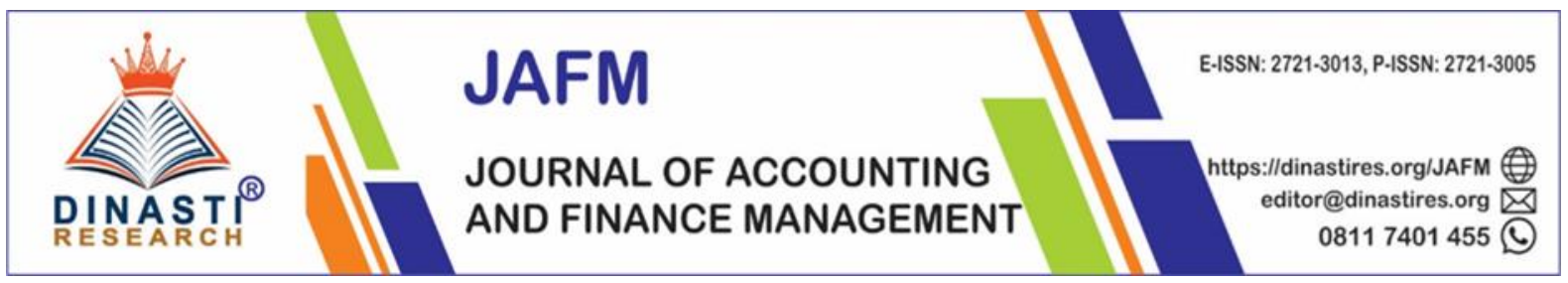

\title{
The Management of Character Education in Schools Around Pesantren Environment to Build Akhlakul Karimah
}

\author{
Deti Rostini $^{1^{*}}$, Atabik Zuhdi², Vidia Lantari Ayundhari ${ }^{3}$ \\ ${ }^{1)}$ Universitas Islam Nusantara, Indonesia, detirostini@spsuninus.ac.id \\ ${ }^{2)}$ Universitas Islam Nusantara, Indonesia, atabik.zuhdi@gmail.com \\ ${ }^{3)}$ Balai Diklat Keagamaan Bandung, Indonesia, ayundhari.vidia@gmail.com
}

Corresponding author: Deti Rostini ${ }^{1}$

\begin{abstract}
Character education in Islam has existed since Prophet Muhammad's period. "Pesantren" or Islamic boarding school is a place of character building in obedience to "Kaffah" Islamic teachings. The character education in schools here means, a process of building good character or Akhlakul Karimah by presenting education model of pesantren but realized in formal institutions. It is deemed as solution for children who do hesitate to have boarding school education because of several reasons. This study aims to describe the implementation of character education management in senior high schools around boarding schools environment located in Banyumas, Central Java. The approach used in this research is a qualitative with descriptive method. The character education in Banyumas has implemented four modern management functions in a proportional way by upholding the tutor role of Pesantren.. The cooperation has been running simultaneously and run conventionally, while still adhering the management principles even need a various ongoing renewal efforts.
\end{abstract}

Keywords: Management, Character Education, Islamic Boarding School

\section{INTRODUCTION}

The urgency of instilling moral values is increasingly evident, seeing many cases of juvenile delinquency that demonstrates a considerable increase in these last few years. The data reported by the National Commission on Child Protection shows that criminals from teenagers and children have increased. From January to October 2009, the behavior of delinquency in adolescents increased by 35\% compared to the previous year. The culprit on average aged 13 to 17 , the case of drug abuse annually increasingly penetrated the youth market, both from age factor and education, and young drug users experienced an increase in the year 2010. Based on age factor, the youngest drug user arrested was recorded between 14 and 19 years old (Aroma \& Suminar, 2012).

This forementioned condition raises more concern on the parents. The parents are 
aware to instill noble character and morality over children earlier, and they believe boarding school (Pesantren) is the right educational institution dealing with Islamic behaviour and praises. Pesantren contributes positive elements to the nation and has its own formation both dimension of education and special learning. Due to the importance of pesantren in education, making Ki Hajar Dewantara as a national figure to put pesantren parallel to the modern school system even as a determinant of the national construction (Baso, 2012: 30). Sociological ability of boarding schools in adopting modern system not only because them are able to make adjustments and readjustment, but because of its existence. According to Nurcholis Madjid as quoted by Masykhur (2010: 37), pesantren is an institution that is not only identical with Islam, but also identical with the authenticity of Indonesia (indigenous).

This research is taking locations in three high schools located around boardingschools' environment of Banyumas, Central Java. Based on preliminary observation, information obtained was about parents' community in Banyumas expected that their children to have noble morality, obey the teachings, and avoid moral decadence. Parents want their children to have Akhlakul Karimah by learning and becoming students in boarding schools. However, on the other hand, they are not willing to stay in pesantren for a variety of reasons. Therefore, the solution that is taken by the parents is to include their children to the formal school but managed by a boarding school for their mental and spiritual development, so that Akhlakul Karimah and "Kaffah" Islamic teachings can be realized.

Managing the process of character education by the standard of National Education and Islamic boarding while realizing society's and pesantren's expectation, certainly requires professional management. This research describes educational management of three schools around pesantren to equip The Science and Technology (IPTEK) competence to the students. This research used Terry's theory (2006: 395-396), where there are four management functions cannot be separated from one another. All four functions are planning, organizing, actuating, and controlling.

Beside using the theory, this study also took the philosophical foundation of Progressivism. This flow has provided the foundation of positive freedom to students both physic and psychic, as well as a systematic way of thinking in exploring skills and competencies that are hidden on themselves without barriers and obstacles This flow sees that people with potential and competence of intelligence can exploit them as a device for life, achieve prosperous life, and thus human beings could develop their personality.

This research aims to find out how is character education implemented through educational management (planning, organizing, actuating, and controlling) in three high schools around pesantren environment Banyumas to build Akhlakul Karimah.

\section{METHODS}

The method used is field research and qualitative approach with descriptive method. The data collected was derived from the research site. The data source consists of two types; unwritten data, i.e. words, actions, and events related to the learning process and written data, which is a record in all forms of documents that exist in three high schools around pesantren. The subjects are the caregivers as the duty holders, the school principal, vice principal, religion teacher and also teacher council which accurately understands the ins and outs of implementing learning activities in character building.

The data source is a primary and secondary source. The primary source is a source that directly provides the data to researchers, while secondary sources do not, but through others or through documents (Sugiyono, 2014:187). The data collection steps are in the formof data reduction, display data, draw conclusions and verify data retrieval is conducted with obstetrications, interviews, and document studies. 


\section{RESULTS AND DISCUSSION \\ Planning}

In planning, these three high schools have used a scheme of 5W1H. 1. Why education characters are important to be instilled, because schools and pesantren carry out the trust of society in shaping Akhlakul Karimah, and also to fortify students from moral decadence. 2. What is prepared to realize the objectives is the education process which conceptualized, managed, and charged to character-based. 3. High schools with pesantren design the definitive place/particular location to perform the activity where character education is implemented. 4. The when implementation follows scheduling intracurricular, co-curricular, and extra- curricular activities. Meanwhile, the who implement character education is teachers or mentors who meets the academic qualifications and competency of Islamic sciences. And How character education implemented is by a series of activities from preparing components of education: local content curriculum, materials, methods, places, times, school citizen's readiness and caregivers' policy as well as actively involving various educational elements. Planning starts from setting vision and mission, local curriculum, rules, order, punishments, and either character education procedures at school.

\section{Implementation}

Organizing conducted before implementing post-planning management phase. It executed using four components: work division, implementers, environmental coordination, and relation between parts. Division done based on existing competencies and resources. It was arranged by the school in coordination with parties and pesantren.

The character education implementation in schools began since they were enrolled as new students. Character educator materials is relatively equivalent to the leader's character which is formed by giving students a chance to lead the discussion, and daily religious ritual activities. Islamic Religion Education (IRE) values are implanted by mastering four materials, such as Tauhid, Fiqh, Hadist Qur'an and Islamic history. Lessons about Tauhid is learnt through the books of Al-Jawahir al-Kalamiyyah, and Niyat Ingsun Ngaji written by KH. Badawi Hanafi, the founder of Pesantren Al-Ihya Ulumaddin. On the other hand, the 30 juz of Al-Quran, Hadits of Al-Arba'in al-Nawawiyyah must be memorized. Fiqh is instilled to their worship's consciousness, and through the subjects of IRE Plus that coupledto recite The Yellow Book's (Kitab Kuning) reading. The historical material of Prophet Muhmammad SAW was taught through the book of Al-Barzanji and Khulasah Nurul Yaqin. And to discipline the students, they were obliged to pray in the beginning of time. Various Islamic characters were instilled through the activities referred to Nahdlatul Ulama's references.

\section{Evaluation}

Several supervisory actions that have been performed in character education implementation include the followings.

1) Controlling during activities is conducted through monitoring, and evaluating results of the school-based characters achievement. Monitoring is a visit to parents'home if the student been absent from school over 3 days.

2) Monitoring daily activities in schools can be in form of Friday prayer. Male students must perform the prayer in the school mosque or nearby, as a means of evaluating and monitoring them so that unobedient students can be possiblypenalized. The rest female students are obliged to pray Dzuhur and given the literacy of Muslimah's (female muslim) jurisprudence and repatriated together afterwards.

3) Evaluation is conducted in coordination meeting attended by the school leaders, teachers of boarding schools, and foundations to assess the process, especially on 
religious learning and typical Islamic characters values. The evaluation of student behaviour is done by sharing and hearing input from various parties, and teachers to get feedback. School patrols are also conducted to anticipate the students' behavior who break the rules and (or) roam at school hours.

4) Annual evaluation is to control local content, following-up is permitted if the objective has not yet reached. Students who have not met the target of Juz Qur'an, for instance, would get either treatment or punishment. Punishment can be in formof reading Surah Yaseen five times to each material that has not been memorized, but still obliged to meet the predefined standards. The treatment is technically facing a teacher who has been appointed to serve the students making improvements to what has not been mastered.

\section{The Cooperation among Institutions due to The Character Education Implementation around Pesantren Environment}

Boarding school and the foundation are the first and foremost partner in the implementation of character education in schools, because pesantren is an inspirator as well as a single reference of character and Akhlakul Karimah formation. The transferred values refer to the policy line, the vision, and mission of boarding schools. Government institutions are also invited to cooperate with the school. Take an example of one vocational school that cooperates with Indonesian National Army or the police headquarters in terms of building discipline. Cooperation with the school Committee and students' guardian is essential and prevailed as strategic factor to socialize education process of Pesantren. The education agency is also a place to share, consult and discuss between partners for schools, especially about the government policy. Both village and subdistrictgovernment are also parties which contribute greatly to the implementation, for they become regional factor as well as an external supervisor for schools and pesantren.

\section{CONCLUSIONS}

In general, the implementation of character education in schools around pesantren environment uses the concept of mixed management. The combination of modern values enforced in schools combined to boarding schools' management that is centralistic and dominated by pesantren's policy. Character education is instilled to the students in terms of building Akhlakul Karimah to fulfill parents' will who expect their children being faithful and kind. The four management functions have been applied in line with the principle of planning, organizing, actuating, and controlling, though it is far still from the perfection, needs renewal efforts, and ongoing improvement.

The establishment of public schools around pesantren environment is proof that Pesantren has a process of convergence and openness as well as the form of accommodation to the demands of change, modernization, and technical concept of education by transferring the tradition to provide various skills to their students, while adhering Akhlakul Karimah.

The planning of character education has meet $5 \mathrm{~W}$ and $1 \mathrm{H}$ aspects. Organizing character education is running with a centralistic system. The actuating involves all potential and elements of education in the school. The controlling on the course of character education in schools around pesantren environment has been in accordance with supervision management. Last but not least, several parties have worked with the school as an institution that carries out the trust to conduct character education.

\section{REFERENCES}

Aroma, I. S., Suminar, D.R. 2012. Hubungan Antara Tingkat Kontrol Diri Dengan Kecenderungan Perilaku Kenakalan Remaja. Jurnal Psikologi Pendidikan dan 
Perkembangan [online], 01 2, pp.1-6.

Baso, Ahmad. (2012). Pesantren Studies 2a. Jakarta: Pustaka Afid.

Depdiknas RI. 2003. Undang-undang No. 20. Tahun 2003 Tentang Sistem Pendidikan Nasional. Jakarta: Depdiknas.

Depdiknas RI. 2007. Undang-undang No. 14. Tahun 2005 Tentang Guru Dan Dosen. Jakarta: Depdiknas.

https://regional.kompas.com/read/2018/02/03/ 10041991/penganiayaan-guru-oleh-siswa-disampang

https://news.detik.com/berita/d-3326185/di-medsos-bocah-sd-melawan-ibu-guru

https://news.detik.com/berita/3569049-jokowi-saya-setuju-pendidikan-karakter-di-pesantrendiperkuat.

Masykhur, Anis. (2010). Menakar Modernisasi Pendidikan Pesantren, Mengusung Sistem Pesantren sebagai Sistem Pendidikan Mandiri. Depok Jabar: Barnea Pustaka.

Sugiyono. (2009). Metode Penelitian Pendidikan. Bandung: Alfabeta.

Terry, George R., (2006). Asas-Asas Menejemen. Bandung: PT ALUMNI, Terjemahan oleh Winardi dari Principles of Management. Illinois U.S.A.: Ricard D Irwin Inc. Homewood, 1977. 